[VOL. XXVII, NO. 3

\title{
CHARITABLE AND NON-PROFIT CORPORATIONS IN ALBERTA - AN UPDATE ON LEGAL AND TAX ISSUES
}

\author{
BY DAVID G. ROBERTS*
}

This legal note surveys a number of legal and tax issues of importance to non-profit corporations in Alberta with special attention to recent proposals for law reform in the area. The author provides a critical analysis of the adequacy of the current laws governing non-profit corporations.

\section{TABLE OF CONTENTS}

I. INTRODUCTION $\ldots \ldots \ldots \ldots \ldots \ldots \ldots \ldots \ldots \ldots \ldots \ldots \ldots \ldots \ldots, 476$

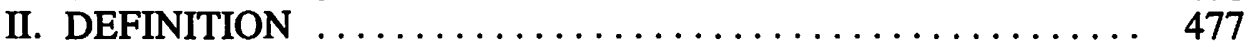

III. ORGANIZATIONAL LEGISLATION $\ldots \ldots \ldots \ldots \ldots \ldots \ldots, 479$

IV. INCOME TAX ISSUES $\ldots \ldots \ldots \ldots \ldots \ldots \ldots \ldots \ldots \ldots \ldots \ldots, 484$

A. INTRODUCTION $\ldots \ldots \ldots \ldots \ldots \ldots \ldots \ldots \ldots \ldots \ldots, 484$

B. REGISTERED CHARITIES $\ldots \ldots \ldots \ldots \ldots \ldots \ldots \ldots \ldots, 485$

C. DONATIONS TO REGISTERED CHARITIES ......... 492

D. NON-PROFIT ORGANIZATIONS $\ldots \ldots \ldots \ldots \ldots \ldots \ldots, 495$

E. IMPLICATIONS OF THE GENERAL

ANTI-AVOIDANCE RULE . . . . . . . . . . . . . . . . . . . . 497

V. CONCLUSION $\ldots \ldots \ldots \ldots \ldots \ldots \ldots \ldots \ldots \ldots \ldots, 498$

\section{INTRODUCTION'}

Charitable and non-profit corporations are among the most common corporations in our society. They are utilized in a wide variety of ways including:

1. to carry on charitable activities, as in the case of a hospital;

2. to raise funds from the public for charitable activities, as in the case of the United Way;

3. to raise funds privately for charitable activities, as in the case of a private foundation;

4. to organize sport and social clubs, trade associations, fraternal orders, and similar groups;

5. to carry on a business; ${ }^{2}$

6. to conduct research; and

7. to effect political, social, or economic change as in the case of advocacy groups.

Obviously, these diverse uses put pressure on both the income tax rules applicable to these various activities and the corporate structure required to carry on these various activities.

* Lawyer with Bennett Jones, Edmonton and Calgary.

1. An earlier draft of this article was presented to a meeting of the Edmonton Tax Discussion Group held October 11, 1988. It incorporates a number of comments received at that meeting.

2. Examples of non-profit organizations carrying on business are contained in the cases considering paragraph 149(1)(l) of the Income Tax Act discussed below. 
Notwithstanding this wide use, these types of corporations are also among the least understood. This result arises because:

1. There are a wide variety of statutes organizing these corporations with a general lack of consistency among those statutes. This can be compared to the statutes organizing for-profit corporations in Canada which are all based on one of three models with most based on the model illustrated by the Canada Business Corporations Act. ${ }^{3}$

2. For-profit corporations have in many Canadian jurisdictions been subjected to corporate law reform and accordingly the relevant legislation reflects current thinking and issues. Meanwhile, the corporate structure for charitable and non-profit organizations has been largely unaltered, at least in Alberta, since the 1920's.

However, a number of recent decisions have given charitable and non-profit organizations a much higher profile. In addition, there has been reform or proposals for reform of the incorporation legislation for these types of organizations in several jurisdictions. In Alberta, the draft Volunteer Incorporations Act was tabled in the Legislature in the spring of $1987 . .^{4}$

The purpose of this article is to review some of the concepts, recent developments and potential problems in this area. It considers three aspects:

1. The definition of "charitable or non-profit corporation".

2. The organizational legislation, at present and as proposed to be amended.

3. The treatment under the Income Tax $\mathrm{Act}^{5}$ of charitable and non-profit organizations and donations thereto.

\section{DEFINITION}

The first key concept is "non-profit". ${ }^{6}$ From a corporate law point of view, the requirement that recurs most frequently is that a non-profit corporation cannot pay dividends to its members. ${ }^{7}$ As an example, subsection 200(1) of the Companies Act ${ }^{8}$ provides as follows:

"When an association has been or is about to be formed as a limited company, if it proves to the Registrar that . . . it is the intention of the association to apply the profits, if any, or any other income of the association in promoting its objectives and to prohibit the payment of any dividend to the members of the association, ...."

Similarly, subsection 4(1) of the Societies Act ${ }^{9}$ provides as follows:

"No society shall . . . declare any dividend or distribute its property among its members during the existence of the society."

3. RSC 1985 c. C-44, as amended.

4. 1987 Bill 54 and referred to as the "proposed statute" or the "Volunteer Incorporations Act".

5. RSC 1952 c.148, as amended, and referred to as the "Income Tax Act".

6. "Non-profit" is used throughout this article rather than the more technically correct but less common term "not-for-profit".

7. While both the Societies Act and Part 9 of the Companies Act also require that the incorporation be for certain purposes, the permitted purposes are very broad with the result that the dividend prohibition poses a far more significant constraint. In addition, under the Volunteer Incorporations Act, the purposes of the corporation must be stated but they are not limited.

8. RSA 1980 Chapter C-20, as amended.

9. RSA 1980 Chapter S-18, as amended. 
Neither of these two statutory provisions expressly addresses whether the restriction on dividends applies only during the life of the organization or also on its dissolution, although the Societies Act implies the former. As discussed below, the Volunteer Incorporations Act would require an income distribution restriction effective either only during the corporation's existence or both during its existence and on its dissolution.

The second key concept is "charitable". It was held by the House of Lords in Commissioners for Special Purposes of the Income Tax v. Pemsel ${ }^{10}$ that charitable activities comprised four principal divisions:

(a) advancement of religion;

(b) advancement of education;

(c) relief of poverty; and

(d) other purposes beneficial to the community.

It has subsequently been held" that the fourth division contemplated objects within the spirit and intendment of the instances given in the preamble to the Charitable Uses Act 1601.12

It has been suggested that the mere passage of time and in particular the evolution of the activities of organizations that are generally considered to be charitable from 1601 to 1989 requires a re-examination of this definition. ${ }^{13}$ Nevertheless, in the absence of statutory definition, the decision in Pemsel remains good law. ${ }^{14}$

Two notable qualifications to the meaning of "charitable" are:

(a) It does not include activities for the benefit of oneself or, generally speaking, a narrow group. ${ }^{15}$

(b) It does not include political activities of any kind. ${ }^{16}$

One distinction between the concepts of "charitable" and "non-profit" is that the former results from characteristics of the activity while the latter results from characteristics of the corporation. Accordingly, it is not strictly correct to speak of a "charitable corporation". Further, while a corporation can be non-profit

10. [1891] A.C. 531 at 583 per Lord Macnaghten.

11. See, for example, National Anti-Vivisection Society v. Inland Revenue Commissioners [1947] 2 All E.R. 217 at 220 (H.L.).

12. Headed "an Act to redress the misemployment of lands, goods and stocks of money heretofore given to charitable uses" 43 Eliz. I c.4. The preamble provided as follows:

"Reliefe of aged impotent and poore people, some for maintenance of sicke and maymed souldiers and marriners, schooles of learninge, free schooles and schollers in universities, some for repaire of bridges, portes, havens, causewaies, churches, seabanks and highwaies, some for education and pfermente of orphans, some for or towards reliefe stocke or maintenance for houses of correcceon, some for mariages of poor maides, some for supportacon ayde and helpe of younge tradesmen, handcraftesmen, and psons decayed, and others for reliefe or redemption of prisoners or captive, and for aid or ease of any poore inhabitant concninge paymente of fifteenes, settinge out of souldiers and other taxes".

13. See Drache, The Canadian Taxpayer, Vol. X:15 (August 2, 1988), 119.

14. See, for example, Native Communications Society of B.C. v. M.N.R. 86 DTC 6353 at 6356 (FCA).

15. Waters, Law of Trusts in Canada (Second Edition) (Carswell, Toronto, 1984) 557 et. seq and The Seventh Division, Pacific Northwest Region, National Model Railroad Assocation v. The Queen 89 DTC 5133 (FCA).

16. Waters, Id. 586 and Re Public Trustee and Toronto Humane Society (1987) 60 O.R. (2d) 236 (HCJ). This has been an issue in several income tax cases recently and is discussed further below. 
without carrying on charitable activities, it is not clear that activities could be considered charitable if they were carried on by a corporation that was not nonprofit. ${ }^{17}$ Accordingly, where this article refers to charitable corporations, it refers to those non-profit corporations that carry on charitable activities and where it refers to non-profit corporations, it refers to those that are non-profit but do not carry on charitable activities.

\section{ORGANIZATIONAL LEGISLATION}

At the present, the principal statutes providing for the incorporation of non-profit corporations in Alberta are:

1. Societies Act;

2. Religious Societies' Land Act; ${ }^{18}$

3. Companies Act; and

4. Canada Corporations Act. ${ }^{19}$

In addition, there are a number of other statutes providing for the incorporation of particular types of non-profit organizations. They include the Cemetery Companies Act ${ }^{20}$, the Agricultural Societies Act ${ }^{21}$, the Womens' Institute $\mathrm{Act}^{22}$, and Part 4 of the Hospitals Act. ${ }^{23}$ Also, some non-profit corporations are incorporated by a private act of the Legislature.

Each of these statutes results in the formation of a corporation. For example, under the Societies Act:

"10. From the date of the certificate of incorporation, the subscribers to the application and the other persons that from time to time become members of the society are a corporation and have all the powers, rights and immunities vested by law in that corporation."

In each case, although to varying extents, the respective statutes ascribe additional characteristics to the corporation. In addition, section 16 of the Interpretation $\mathrm{Act}^{24}$ would apply to each such corporation. It provides as follows:

"Words in an enactment establishing a corporation:

(a) vest in a corporation power

(i) to sue in its corporate name,

(ii) to contract and be contracted with by its corporate name,

(iii) to have a common seal and to alter or change it at pleasure,

(iv) to have perpetual succession,

(v) to acquire and hold real property and personal property for the purposes for which the corporation is established and to dispose of the real property or personal property at pleasure, and

(vi) to regulate its own procedure and business;

(b) make the corporation liable to be sued in its corporate name;

(c) vest in a majority of the members of the corporation the power to bind the others by their acts;

17. Consider, for example, a for-profit hospital or hospital management corporation.

18. RSA 1980 c. R-14, as amended.

19. RSC 1970 c. C-32 (not consolidated in RSC 1985).

20. RSA 1980 c. C-3.

21. RSA 1980 c. A-12.

22. RSA 1980 c. W-13.

23. RSA 1980 c. $\mathrm{H}-11$, as amended.

24. RSA 1980 c. I-7. 
(d) exempt from personal liability for its debts, obligations or acts those individual members of the corporation who do not contravene the provisions of the enactment establishing the corporation ...."

A similar provision in respect of federal corporations is found in Section 21 of the Interpretation Act. ${ }^{25}$

Generally, each of the principal statutes governing non-profit corporations does not reflect a number of the advances in corporate law, advances which are reflected in modern business corporation statutes. ${ }^{26}$

It was in this context that the Institute of Law Research and Reform issued its report proposing an incorporated associations act for Alberta that would replace the Societies Act and the Companies Act ${ }^{27}$ It proposed to leave unaltered the other statutes referred to above. ${ }^{28}$ This apparently reflected a policy decision based upon the experience of the federal government in connection with a reform of the Canada Corporations Act. Bill 54 was introduced into the Alberta legislature in the spring of 1987 proposing the enactment of the "Volunteer Incorporations Act".

The following general comments can be made with respect to the proposed statute:

1. Even if the pure non-profit aspects are ignored, the proposed statute contains elements of the Business Corporations Act, ${ }^{29}$ the Societies Act, and the Companies Act.

2. One of the objectives of the Institute in preparing its report was to keep the statute as simple as possible in order that legal advice would not be required by these organizations. ${ }^{30}$ While this is a laudable objective, the practical matter is that the same argument existed for a substantial number of for-profit companies under the Companies Act, but that did not result in the Business Corporations Act being simplified or more closely tracking the Companies Act to minimize those problems. ${ }^{31}$

3. While the Business Corporations Act deliberately conforms to the general statutory language and format utilized in the Canada Business Corporations Act and in several other provincial for-profit corporation statutes, there is no suggestion by the Institute that the proposed statute follows the model of any other non-profit corporation statute. Consequently, advantages similar to those resulting from the relative uniformity of for-profit corporation statutes would not be achieved.

4. Prior to the enactment of the Business Corporations Act, it was possible to incorporate a non-profit corporation under the Companies Act that was subject to the same rules as those which governed most for-profit corporations. However, if the proposed statute is enacted, even ignoring the other special

25. RSC 1985 c. I-21.

26. Institute of Law Research and Reform, Proposals for a New Alberta Incorporated Associations Act (Report No. 49) (Edmonton, 1987) 6, 13.

27. Id.

28. Supra n.26 at 7 .

29. SA 1981 c. B-15, as amended.

30. Supra n.26 at 20-21.

31. In fact, the Companies Act and the Business Corporations Act are radically different. 
purpose non-profit statutes, the for-profit and non-profit legislation will differ beyond the changes necessarily required by a "non-profit" statute. ${ }^{32}$ The resulting inability to apply for-profit case law on corporate matters to nonprofit organizations (since there will likely always be more such case law with respect to for-profit corporations than with respect to non-profit organizations) and lack of familiarity with non-profit corporations may in the long run be undesirable.

In view of the present uncertainty with respect to the status of the proposed statute, it is not reviewed in detail. However, the following aspects are summarized below:

1. Continuance;

2. Distribution restriction;

3. Purposes, powers and constructive notice;

4. Directors' liabilities;

5. Other matters.

When the Business Corporations Act came into force, it provided a mechanism by which for-profit corporations under the Companies Act continued under the Business Corporations Act by preparing and filing documents analogous to incorporation documents. While that approach required significant efforts by companies (as compared to the position had the statute simply deemed such companies to be continued), it had several advantages:

1. Each corporation's constating documents had to be reviewed and consolidated;

2. The provisions of the Companies Act dealing with for-profit organizations could thereafter largely be ignored;

3. The Registrar of Corporations was able to close its files on a large number of companies that did not continue; and

4. The likelihood of a corporation having a provision in its constating documents that was overridden by the Business Corporations Act was minimized.

The proposed statute does not contain a similar continuance requirement for non-profit organizations. This follows the recommendation of the Institute. The Institute offered two reasons for this approach.$^{33}$ First, members of non-profit organizations do not have the same economic interest in the organization that shareholders of for-profit corporations do and consequently there is a much smaller risk of harm as a result of imposing new rules upon an un-updated structure. Second, the obligation to continue was seen as more onerous in the case of non-profit organizations because most lack legal advice. ${ }^{34}$ The Institute proposed that the new statute apply automatically to existing non-profit companies and societies with the original constating documents being deemed to be articles of incorporation and by-laws under the new statute. The proposed statute also contains a provision that

32. Supra $\mathrm{n} .26$ at 21 .

33. Supra n.26 at $40-43$.

34. Although, also because most lack legal advice, the danger that a non-profit organization would rely upon its constating documents without realizing that they may be overridden by the statute would be significant. 
[VOL. XXVII, NO. 3

would invalidate any provision of a constating document of an existing company or society that would contravene the new statute..$^{35}$

The proposed statute would require that the organization be subject to either an income distribution restriction or an income and liquidation distribution restriction. ${ }^{36}$ The former would be a prohibition against the declaration of dividends and the distribution of income to members during the existence of the organization, while the latter would be a similar prohibition that would apply both during the existence of the organization and upon its dissolution. Express exceptions would be made in the case of payments for goods or services rendered and for reimbursement of expenses. As discussed further below, this restriction is essential for either registered charity status or non-profit organization status under the Income Tax Act. ${ }^{37}$

Both societies and Part 9 companies are subject to the traditional lack of capacity of a company to carry on activities other than those expressly provided for in its constating documents. ${ }^{38}$ They do not have the powers of a natural person as does a Business Corporations Act corporation. In addition, both the Societies Act and Part 9 of the Companies Act restrict the purposes for which a non-profit organization may be incorporated. Under the Societies Act, a non-profit organization may be incorporated for a benevolent, philanthropic, charitable, provident, scientific, artistic, literary, social, educational, agricultural, sporting or other useful purpose, but not for the purpose of carrying on a trade or business and not for any special purpose for which there is a particular statute in place (such as the Cemetery Companies Act).$^{39}$ Under the Companies Act, a non-profit organization may be incorporated for the purpose of promoting art, science, religion, charity or any other useful object. ${ }^{40}$

Under the proposed statute, a non-profit organization could be incorporated for any purpose, including the carrying on of a business for the profit of the organization (as opposed to the profit of its members). ${ }^{41}$ It must be remembered that the incorporation of an organization under this statute would not guarantee tax exempt status under the Income Tax Act.

While there would be no limitation on the purposes for which an organization may be incorporated, the organizational documents must set out the purposes of the association and its permitted activities would be limited to those purposes. The reason suggested for this distinction from the provisions of the Business Corporations Act is that a non-profit organization is usually formed for a specific purpose and members should be able to confine its activities to those purposes, subject to the ability to amend the purposes. ${ }^{42}$

Notwithstanding the restriction on activities resulting from the stated purposes, the Institute was concerned to ensure that the ultra vires rule would not apply and

35. Subsections $10(4)$ and $11(4)$.

36. Section 5 and also see Institute of Law Research and Reform, supra $\mathbf{n} .26$ at 26.

37. Paragraphs 149(1)(1), 149.1(1)(a), and 149.1(1)(b).

38. Ashbury Railway Carriage and Iron Co. v. Riche (1875) L.R. 7 E \& I App. 653. This is often described as the ultra vires rule.

39. Section 3.

40. Subsection $200(1)$.

41. Supra $\mathrm{n} .26$ at $30-32$.

42. Supra n.26 at 33. 
the proposed statute expressly states that the organization has the capacity of a natural person. ${ }^{43}$ It is prohibited from exercising its powers except for the purposes stated but any act would not be invalid simply because it is contrary to the articles. ${ }^{44}$

Directors would be required to act honestly and in good faith with a view to the best interests of the corporation, and also to exercise the care, diligence and skill that a reasonably prudent person would exercise in comparable circumstances. ${ }^{45}$ This is the same obligation as under the Business Corporations Act. ${ }^{46}$ The Institute was of the view that the common law was inappropriate in this area and that the reference to comparable circumstances would permit a court to distinguish nonprofit organizations from for-profit organizations ${ }^{47}$ There was concern that the common law would impose an unduly high standard of care on certain directors. The recent decision involving the Toronto Humane Society ${ }^{48}$ suggests that the standard for all directors may be higher, at least in the case of charitable organizations. That decision dealt with a dispute among the members of the Toronto Humane Society, which was a non-profit corporation under the laws of Ontario and a registered charity. The court made a number of notable comments on the role of directors of such an organization:

1. Such an organization is answerable in certain respects for its activities and for the disposition of its property as though it were a trustee and it is subject to the general jurisdiction of the court in that regard. A charitable organization does not have the same freedom to deal with its assets that a for-profit corporation has. It is not sufficient for a charitable organization to simply comply with the governing corporate law..$^{49}$

2. Directors of such an organization are, at least, fiduciaries and are subject to the duties of trustees..$^{\text {so }}$

3. A director of a charitable organization can only receive remuneration where permitted by the court. This would apply even in respect of salaries payable to directors in respect of services rendered to the organization as an officer or employee. ${ }^{\text {sI }}$

4. It is wrong for directors of a charitable organization to operate at the outer edge of what is legally permissible. ${ }^{52}$

In view of the court's conclusion to superimpose trustee obligations on corporate obligations, the duty of care in the proposed statute may co-exist with the common law duty rather than override it as the Institute appears to have intended.

43. Subsection 16(1).

44. Paragraphs 16(3)(a) and 25(a).

45. Section 51.

46. Section 117.

47. Supra n.26 at 51 et. seq.

48. Supra note 16.

49. Id. at 244 and 255.

50. Id. at 246 to 248 .

51. Id. at 247.

52. Id. at 255. 
Unlike the Business Corporations Act, the proposed statute would not impose an obligation upon directors for wages. However, the provisions of the Employment Standards Code ${ }^{53}$ would nevertheless apply.

One other potential liability for directors, likely not affected by the proposed statute, is under Section 227.1 of the Income Tax Act and applies where a corporation either fails to withhold taxes at source or fails to remit amounts withheld. While the reported cases to date dealing with this provision have not dealt with nonprofit organizations, there is no reason why this section could not apply to such organizations..$^{54}$

As noted above, the proposed statute was given first reading in the 1987 spring session. There has been significant public reaction to the bill and matters are on hold for the time being. It appears that the reaction is based upon a perception that the bill would make the operation of non-profit corporations (most of which are presently societies) substantially more complicated. There has been a significant public relations effort by the Department of Consumer and Corporate Affairs to make affected persons more familiar with the proposals. In addition, the Minister of Consumer and Corporate Affairs appointed a task force that is to address whether the proposed statute should be enacted or a new act should be written to replace the proposed statute and, if so, what should be in that new act, and plans for communicating the new rules to non-profit corporations once enacted. The final report is not to be delivered to the Minister until the fall of 1989. Legislative action would be unlikely before 1990 .

\section{INCOME TAX ISSUES}

\section{A. Introduction}

The provision of the Income Tax Act providing exemptions to certain organizations from income tax under Part I of that statute is subsection 149(1). The exemptions that will be considered here (although there are other exemptions that may be relevant for certain types of non-profit organization) are:

"(f) a registered charity;

(l) a club, society or association that, in the opinion of the Minister, was not a charity within the meaning assigned by subsection 149.1(1) and that was organized and operated exclusively for social welfare, civic improvement, pleasure or recreation or for any other purpose except profit ... ;"

Also relevant to registered charities are section 110.1 dealing with the deduction in computing the taxable income of a corporation in respect of gifts to registered charities and section 118.1 dealing with tax credits for such gifts made by individuals. It should be noted that both of these provisions are the result of recent amendments to the Income Tax Act. One of the proposals in tax reform announced by Finance Minister Wilson in June 1987 was the conversion in the case of individuals of the tax benefit resulting from a charitable donation from a deduction to a credit. Sections 110.1 and Section 118.1 provide such a mechanism for individuals while preserving the traditional deduction for corporations and replace former

53. SA 1988 c. E-10.2 section 111.

54. See Drache, The Canadian Taxpayer Vol. IX:10 (May 5, 1987) 72 and Moose Jaw Kinsmen Flying Fins Inc. v. MNR 88 DTC 6099 (FCA). 
paragraph 110(1)(c) which simply provided deductions to all taxpayers for charitable donations.

\section{B. Registered Charities}

Dealing first with registered charities, the Income Tax Act defines "registered charity' as follows:

(a) a charitable onganization, private foundation or public foundation, within the meanings assigned by subsection 149.1(1), that is resident in Canada and was either created or established in Canada, or

(b) a branch, section, parish, congregation or other division of an organization or foundation described in paragraph (a), that is resident in Canada and was either created or established in Canada and that receives donations on its own behalf,

that has applied to the Minister in prescribed form for registration and that is at that time registered as a charitable organization, private foundation or public foundation."'ss

The first step in obtaining registered charity status for an organization is to establish the organization having regard to the particular requirements of the Income Tax Act. The charity could be organized, generally speaking, under one of the statutes set out above, as a trust, or as an unincorporated association although qualification as a foundation (discussed below) would require either a trust or a corporation.

Regardless of how the charity is organized, care must be taken in drafting the objects or purposes. One approach, particularly where dealing with a non-profit corporation organized under Part 9 of the Companies Act, is to draft relatively broad objects (although within the permitted purposes) in order to minimize the possibility that a desired activity would be ultra vires the organization. A general constraint would then be included in the constating document requiring that all activities be charitable. This is consistent with the common practice for for-profit corporations under the Companies Act in the late 1970s and early 1980s (although of course there was no general charitable constraint). This approach results from a desire to ensure that the objects and activities of the organization are constrained only to the extent required by the Income Tax Act by putting the focus of any debate on ultra vires upon the word 'charitable'. However, the Department has taken the view in circumstances of which the author is aware that the objects of a registered charity should be such that they could not possibly include any non-charitable activities. The Department has also questioned the effectiveness of a general restriction. ${ }^{56}$

Once the organization is established, obtaining registration involves the submission to the Department of National Revenue of an application for registration containing copies of the organizational documents and information on the activities and finances of the organization. Recent experience suggests that it will take the Department approximately three months to review the application and provide a response. If it has no questions or concerns, registration is granted at that time. However, if the Department has concerns with the registration application, the time for registration can be extended substantially. A common area of concern (and one that is usually difficult to resolve) is the scope of the organization's activities. The Department generally takes a fairly traditional view of the scope of charitable

55. Subsection 248(1).

56. But see note 80 . 
activities (and, as discussed below, has generally been supported by the courts in this view).

If the application for registration is made reasonably promptly after incorporation/organization, registration is typically granted as of the date of incorporation/organization if that is requested. Otherwise it will be effective as of the date of application. This date is the Department's administrative practice only and there does not appear to be any statutory authority for any particular registration date. A situation where this can be a particular problem is where there is a significant delay in the granting of registration, possibly because of a rejection which is appealed. If the charity is nevertheless operating during that period it may have a significant exposure to income taxes if the effective date of registration is after operations commenced. A possibility which may alleviate this problem in the event of an appeal is to request registration as of a particular date in the pleadings.

To be registered, the organization must qualify as one of the three types of registered charity - "charitable organization", "public foundation", or "private foundation". The distinction between the three types may be summarized as follows:

(a) charitable organization - This is an organization, whether or not incorporated, that carries out charitable activities itself, rather than principally by funding other registered charities. The key requirement is that it devote all of its resources to charitable activities carried on by it. ${ }^{57}$

(b) public foundation - This is a trust or corporation that carries out charitable activities by funding other registered charities and that is not controlled by nor funded principally by one person or a group of non-arm's length persons, other than certain specified persons such as Her Majesty, or a registered charity that is either a charitable organization or a public foundation. Control for these purposes in the case of a corporation is interpreted based upon the test traditionally applicable under the Income Tax Act and is not the same as the de facto control concept which was recently added to certain provisions of the Income Tax Act. It does not have to satisfy the same devotion of resources requirement as a charitable organization but simply must be organized and operated exclusively for charitable purposes. ${ }^{58}$

(c) private foundation - This is a trust or corporation that qualifies as a charity but is not a charitable organization nor a public foundation. It is subject to the same purpose test as a public foundation. ${ }^{59}$

The practice of the Department has not been to reject applications outright, but rather to advise of its concerns and seek information and further submissions. As noted below, this is not required by the case law. If the Department ultimately makes a determination that registration will not be granted, the option available to the applicant is an appeal to the Federal Court of Appeal pursuant to paragraph $172(3)(a)$.

If an appeal is taken, the correspondence between the Department and the applicant in connection with the application will form the record for the purposes of the Federal Court of Appeal. Accordingly, it is important to ensure that all facts

57. Paragraph 149.1(1)(b).

58. Paragraphs 149.1(1)(a) and (g).

59. Paragraphs 149.1(1)(a) and (f). 
that might be relevant are placed before the Department in the course of the initial application or correspondence resulting therefrom. It is also important to ensure that all correspondence with the Department is reviewed as if it were a pleading.

A fact to be kept in mind in the event of an appeal to the Federal Court of Appeal is that its decision can only be appealed to the Supreme Court of Canada. There is no appeal as of right in this type of matter and consequently leave must be sought.

The procedure to be followed by the Minister on an application for registration has only been considered in Scarborough Community Legal Services v. The Queen. ${ }^{60}$ Since the substantive requirements that must be satisfied to obtain registration are largely the same as those that must be met to maintain registration, it is also relevant in this regard to consider a previous decision (In the Matter of Renaissance International v. M.N.R.$^{61}$ ) dealing with the procedure to be followed on a deregistration. These cases stand for the following:

1. A determination that the charity has ceased to comply with the registration requirements of the Income Tax Act and a determination to revoke the registered charity status are quasi-judicial decisions. The Minister must give the charity prior notice of the case against it. There is a duty on the Minister to observe the requirements of natural justice, or at the very least the duty to accord procedural fairness to the charity. The right of appeal to the Federal Court of Appeal is based upon the record as it existed at the time of the decision being made, and such a record would be a unilateral record if there was no obligation to obtain input from the charity first.

2. However, a decision to refuse registration as a charity can be made by the Minister after receiving the necessary information from the appellant, but without advising the appellant in advance of its rejection or its intention to so decide. The Renaissance decision did not apply in the situation of an application for registration. A decision to deny an applicant the right to be given special status on the facts and evidence submitted by him was not an adjudication inter partes such that the decision could be said to be quasijudicial. In addition, the decision to refuse the application was made on the basis of information submitted by the applicant itself. The decision in dealing with an application for registration was purely an administrative decision, rather than one that was subject in its exercise to judicial or quasi-judicial processes.

There have also been several decisions (all of the Federal Court of Appeal as noted above) recently ${ }^{62}$ in which applications for registration have been rejected, and that rejection appealed where more substantive issues have been addressed. The conclusions from these cases are as follows:

1. The interpretation given by the Courts of "charitable" is fairly static. Most of these decisions reflect a fairly strict adherence to long established principles in this area and do not show any significant evolution in the case law.

60. 85 DTC 5102 (FCA).

61. 83 DTC 5024 (FCA).

62. Scarborough Community Legal Services v. The Queen (supra n.60), Native Communications Society of British Columbia v. M.N.R. (supra n.14), Alberta Institute on Mental Retardation v. The Queen 87 DTC 5306 (FCA) (leave refused, SCC), Polish Canadian Television Production Society v. M.N.R. 87 DTC 5216 (FCA), Toronto Volgograd Committee v. M.N.R. 88 DTC 6192 (FCA), Positive Action Against Pornography v. M.N.R. 88 DTC 6186 (FCA), N.D.G. Neighbourhood Association v. Revenue Canada, Taxation Department 88 DTC 6279 (FCA). 
2. The Courts remain very uncomfortable with political activities of any kind and amendments to the Income Tax Act dealing with political activities ${ }^{63}$ would in many cases be irrelevant due to their requirement that the activities be necessary and incidental. ${ }^{64}$ The following points can be noted from these decisions:

(a) There is no distinction between partisan advocacy and political activity. ${ }^{65}$

(b) An organization should not lose its status as a charitable organization because of some quite exceptional and sporadic activity in which it may be momentarily involved and an activity would not be deprived of its charitable nature only because one of its components or some incidental or subservient portion thereof could not, when considered in isolation, be seen as charitable. However, the result is different where a taxpayer made sustained efforts to influence the policy making process and those are an essential part of its actions. ${ }^{66}$

(c) Organizations to foster interchange espouse political causes or aspirations and accordingly are not for the advancement of education. ${ }^{6}$

(d) Social causes may be beneficial to the community but are not within the spirit and intendment of the Statute of Elizabeth. ${ }^{68}$

In any event, there may be a general constraint on any political activities by charitable organizations. In Toronto Humane Society ${ }^{69}$, the court affirmed that political activities were not charitable. The fact that such activities may be acceptable to the Department of National Revenue did not conclude the issue in a non-tax context. ${ }^{70}$

3. There are a number of interesting comments on the Department's administrative policy on political activities contained in the decisions. They include the following:

(a) The making of written or oral representations to an elected representative in order to present the organization's interest and point of view is not an activity that would itself be political. ${ }^{71}$

(b) The presentation of briefs to commissions or committees setting out its views on matters related to its charitable mandate and recommending corrective measures would not be political. ${ }^{72}$

(c) However, attempting to influence a governmental stance or action through demand or pressure tactics including lobbying, public demon-

63. Principally subsections $149.1(6.1)$ and (6.2)

64. For an article addressing the same issue under the Internal Revenue Code, see Beth Sabbath, "Tax Exempt Political Education Organizations Is the Exemption being Abused?" (1988) 41:4 The Tax Lawyer (American Bar Association, Chicago) 847.

65. Scarborough Community Legal Services, supra n.62 at 5106.

66. Id. 5107.

67. Toronto Volgograd Commintee, supra $\mathbf{n} .62$ at 6198.

68. N.D.G. Neighbourhood Association, supra n.62 at 6282.

69. Supra n. 16 at 248 et. seq.

70. Id. 251, 252, 254.

71. N.D.G. Neighbourhood Association, supra n.62 at 6283.

72. Id. 
strations, solicitation of the public to engage in letter writing campaigns or the support or opposition of specific candidates is not charitable. ${ }^{73}$ The Department had stated its policy in this area in the late 1970's. ${ }^{74}$ As a result of adverse public reaction, it was withdrawn notwithstanding that it represented the law and the Department's policy at the time. Following the amendments to the Income Tax Act dealing with incidental political activities noted above, the Department restated its policy ${ }^{75}$ on this issue. The comments referred to above from these decisions are consistent with both of these statements of policy.

4. In contrast to their position with respect to political activities, the courts are taking a more flexible view on fund raising activities. In Alberta Institute on Mental Retardation v. The Queen, the majority took the view that a charity is not carrying on a business if all of the monies received are dedicated to charitable purposes and the business aspect of the operation was merely incidental to the attainment of its charitable objects. There is no other authority on this point. Even without this decision, fund raising activities that are a "related business" are acceptable. That is defined to include a business in which substantially all of the people employed are not remunerated. ${ }^{76}$

5. For activities to qualify as educational, they must not be biased. Advancement of education was recognized to include the training of the mind and the improvement of a useful branch of human knowledge and its public dissemination. The presentation to the public of selected items of information and opinion on a particular subject is not educational in the charitable sense of that term. ${ }^{77}$

6. There is a difference between "charitable activities" in defining charitable organizations and "charitable purposes" in defining public and private foundations. ${ }^{78}$ However, purposes can be considered in connection with an application of a charitable organization to determine whether its proposed activities, assuming that they are consistent with its purposes, would qualify. ${ }^{79}$

7. Broadly phrased corporate objects clauses for a charity are not necessarily unacceptable. A general requirement that purposes be carried out on an exclusively charitable basis is effective. Also relevant is a provision requiring that, on dissolution, property be transferred to another registered charity. ${ }^{80}$

8. The proper treatment of "ethnic charities" remains an unsettled area. ${ }^{81}$

To maintain registered charity status, it is necessary to satisfy two requirements. The first is continuing to meet all the requirements applicable in respect of the grant

73. Id.

74. Information Circular IC 78-3 (withdrawn).

75. Information Circular IC 87-1.

76. Paragraph 149.1(1)(j).

77. Positive Action Against Pornography, supra n.62 at 6189 and 6190.

78. Scarborough Community Legal Services, supra n.62 at 5106.

79. Toronto Volgograd Committee, supra n.62 at 6196.

80. Native Communications Society of B.C., supra n.62 at 6359.

81. Contrast Native Communications Society of B.C., (supra n.62) and Polish Canadian Television Production Society, (supra n.62). 
of the status. As noted above, these requirements vary among the three types of registered charities. The second is to meet certain specific requirements that again depend upon the type of registered charity. These include, for example, carrying on only related businesses and, for charities that are not charitable organizations, not acquiring control of a corporation and not incurring certain debts. One of these requirements that applies to all registered charities is the satisfaction of certain disbursement requirements.

Generally speaking, of the three types of registered charities, the disbursement requirement is highest for a private foundation, drops somewhat for a public foundation, and drops significantly for a charitable organization..$^{82}$ The disbursement requirement for a private foundation in a particular year is an amount equal to the aggregate of, generally speaking, $80 \%$ of receipted donations in the previous year, $100 \%$ of gifts from other charities, and $4.5 \%$ of assets not used directly in charitable activities. The last element is to ensure that such assets are invested in a way that earns a reasonable return. For a public foundation, the requirement is the same, except that it is only required to disburse an amount equal to $80 \%$ of funds received from other charities. For charitable organizations, it is only necessary to disburse an amount equal to $80 \%$ of receipted donations. Consequently, there is often a strong incentive when applying for registered charity status to seek the charitable organization designation. However, for many charities, the amount required to be disbursed may be approximately the same, regardless of their designation.

The Income Tax Act contemplates two methods of satisfying these disbursement requirements. First, a charity can make gifts to qualified donees (generally speaking, other registered charities and Her Majesty). ${ }^{83}$ While public and private foundations have no restriction on such gifts, charitable organizations are restricted as described below. Second, a charity can carry on charitable activities directly.

While the disbursement requirement for charitable organizations is the lowest of the three, there is also the general requirement noted previously that a charitable organization must devote all of its resources to charitable activities carried on by it. This is generally understood (although in the absence of significant case law) to mean that:

1. making gifts to other registered charities; and

2. making gifts to other organizations that are not registered charities for them to spend in the course of their charitable activities;

are not acceptable disbursements.

With respect to gifts to other registered charities by a charitable organization, the Income Tax Act does provide some relief since it contains a provision deeming certain gifts to be a devotion of resources to charitable activities carried on by the charitable organization. ${ }^{84}$ This deeming rule will apply to the extent that the organization disburses not more than $50 \%$ of its income in a particular taxation year to other registered charities. This formula creates a number of difficulties. The most obvious one is whether it is possible to make a gift out of capital or whether the gift must be out of income in order to be within this provision. It must be remembered that, but for this rule, a charitable organization cannot make gifts to other charities

82. Paragraphs 149.1(2)(b), 149.1(3)(b), 149.1(4)(b) and 149.1(1)(e).

83. Paragraph 149.1(1)(h).

84. Paragraph 149.1(6)(b). 
and accordingly the deeming rule is actually an exception. Second, because it is not a cumulative test in any way, it is not possible to rely upon this test to make a gift to other registered charities immediately after the end of a fiscal year. Such gifts would be assessed based on the income for the subsequent fiscal year even though the amount might have been determined based on income for the previous year.

One way around this restriction is to have the charitable organization associated with another charity. ${ }^{85}$ Association requires that there be substantially the same charitable aims or activities. Such an application can be effective as of any date specified by the Minister. The effect of that application is that a charitable organization can disburse income to a registered charity without limitation. However, there is still no ability to disburse an amount that is not income. In this regard, it is necessary to note that income is defined specifically for registered charities. ${ }^{86}$ It should also be noted that, between associated charities, income can be distributed either in the year that it is earned or in any other year (although there may be an argument that income becomes capital if it is held after the year in which it is earned).

With respect to gifts to organizations that are not registered charities, the Department requires administratively that there be "direction, control and supervision"' ${ }^{87}$ Effectively, they are looking for a joint venture, agency, or employment type arrangement by which the activities of that other organization can be characterized as the activities of the registered charity. This can be a particular problem when gifts are made to organizations in Third World countries. They may not have sophisticated financial controls or record keeping. They also may not have any interest in joint venture arrangements or similar arrangements. Nevertheless, it is often fairly easy to see that the activities of the other organization (for example, operating a school or feeding malnourished children) are charitable. This is an area of real difficulty for many organizations.

In all cases where expenditures outside Canada are being considered, it is worthwhile to review the provisions of the tax treaty between Canada and the other jurisdiction, if one exists. As an example, the treaty between Canada and the U.S. provides that:

\begin{abstract}
"For the purposes of Canadian taxation, gifts by a resident of Canada to an organization which is resident in the United States, which is generally exempt from United States tax and which could qualify in Canada to receive deductible gifts if it were created or established and resident in Canada shall be treated as gifts to a registered charity; however, such gifts (other than such gifts to a college or university at which the resident or a member of his family is or was enrolled) shall not be deductible in any taxable year to the extent that they exceed an amount determined by applying the percentage limitations of the laws of Canada in respect of the deductibility of gifts to registered charities to the income of such resident arising in the United States. The preceding sentence shall not be interpreted to allow in any taxable year deductions for gifts to registered charities in excess of the amount allowed under the percentage limitations of the laws of Canada in respect of the deductibility of gifts to registered charities"'.88
\end{abstract}

85. Subsection 149.1(7) and paragraph 149.1(6)(c).

86. Paragraph 149.1(12)(b).

87. See paragraph 19 of IC $80-10$ R. The policy has been set out in letters to charities and is described in detail in Drache, Canadian Taxation of Charities and Donations (DeBoo) 2-22 et. seq.

88. Canada U.S. 1980 Tax Convention, Article XXI(6). 
It may be argued that this provision effectively permits gifts to be made by a Canadian registered charity to a $501(\mathrm{c})(3)^{89}$ organization under the Internal Revenue Code taking the position that gifts to such an organization have the same effect as gifts to registered charities. This is not consistent with the explanation of this provision of the convention issued by the United States Department of the Treasury (which has been accepted by the Department of National Revenue) and the Department of National Revenue has also specifically disagreed with this position in one case of which the author is aware.

\section{Donations to Registered Charities}

As noted previously, one of the attributes of registered charities is that gifts to such organizations offer the donor either a deduction in computing taxable income or a tax credit. It is necessary to consider the interpretation of "gift" in this context. This has been addressed in both a business context and a non-business context.

In a business context it has been held that donations to a charity made for the purpose of earning business income are deductible as business expenses and therefore were not subject to the $20 \%$ of income limitation that would be applicable to the donation if it were a charitable gift. ${ }^{90}$

In a non-business context, the issue has also been the presence of ulterior motives for the donation:

1. In The Queen v. McBurney, ${ }^{91}$ amounts paid to Christian religious schools attended at various times by the donor's children were held not to be gifts. However, the court was prepared to allow the payments to be characterized as gifts to the extent permitted under the Department's administrative policy.

2. In Tite v. M.N.R. ${ }^{92}$ the Court dealt with the sale by a registered charity of a Robert Bateman print for an amount allegedly in excess of its fair market value with the excess being characterized as a receipted donation. The Court held that there was a contractual relationship between the taxpayer and the Canadian Wildlife Federation and that there was no gift made because the transfer did not arise because of detached or disinterested generosity. Rather, the taxpayer received some valuable consideration in retum for the payment.

3. In Burns v. The Queen ${ }^{93}$ a dentist made donations to the Canadian Ski Association at a time when his daughter was a member of one of the ski teams sponsored by that organization. It was held that the amounts were not gifts and accordingly were not deductible because they were payments made for the purpose of securing a material advantage for the taxpayer. The court concluded that, even if there was no contractual obligation, the payments were not made without consideration and without benefit. The court's view was that the essential element of a gift is that the donor must be willing to grow poorer for the benefit of the donee without receiving any compensation. In this case, the taxpayer believed that he was paying for his daughter's ski training and there was not the necessary intention.

89. An approximate equivalent to a registered charity.

90. Olympia Floor \& Wall Tile v. M.N.R. 70 DTC 6085 (Ex) and Impenco v. M.N.R. 88 DTC 1242 (TCC).

91. 85 DTC 5433 (FCA).

92. 86 DTC 1788 (TCC).

93. 88 DTC 6101 (FCTD) (under appeal). 
These cases, while justifiable on their own, also raise concerns in seemingly acceptable donations. For example, consider a donor who proposes to transfer real property to a registered charity as a donation. The value of the property is $\$ 200,000.00$. It is encumbered by a mortgage having an outstanding principal balance of $\$ 50,000.00$. There may be an argument that the agreement by the charity to assume the obligation under the mortgage (whether express or implied by Section 62 of the Land Titles Act ${ }^{24}$ ) would result in the charity having delivered consideration to the donor with the result that the donor would not be entitled to any tax relief notwithstanding a donation worth $\$ 150,000$. It may be possible to overcome this problem by arranging a gift of the equity in the property although the distinction between a transfer of the equity and a transfer of the property subject to the mortgage may be too narrow to avoid this problem.

Technically, the same issue arises with respect to items or events intended to recognize donors. Practically, there should not be a problem where these items or events are not of a significant value relative to the amount of the gift. ${ }^{95}$

It should be noted that, notwithstanding the cases referred to above, the Department expressly permits an allocation between gift and non-gift portions in certain circumstances. ${ }^{96}$ These circumstances include a ticket to attend a dinner, ball, concert, show or a like event.

Receiving either a deduction or credit for a gift to a registered charity requires that the donor have a receipt. A receipt issued by a registered charity must contain certain information. ${ }^{97}$ Care must be taken because one of the grounds for revocation of a charity's registration is the improper issuance of a receipt. ${ }^{98}$

Certain types of gifts are more advantageous for a charity. As noted above, it is generally the case that expenditures on charitable activities in a year must exceed $80 \%$ of receipted donations for the preceding year. However, certain gifts are exempt from that requirement, with the result that such gifts need never be disbursed on charitable activities by a charitable organization (although it would remain necessary to ensure that all resources are devoted to charitable activities) and would only have to be disbursed by a public or private foundation by virtue of the $4.5 \%$ return on assets test (assuming that it was operated exclusively for charitable purposes). The gifts that qualify for this preferential treatment are the following:

(a) a gift of capital received by way of bequest or inheritance. ${ }^{99}$ There is some doubt as to precisely what is meant by a gift of capital. Is this assessed from the view of the donor or the charity? Does this mean that it must have attached to it a condition that it be held for some time? Does this imply that it cannot be used to cover operating expenses?

(b) a gift received subject to a trust or direction to the effect that the property given, or property substituted therefor, is to be held by the charity for a period of not less than 10 years. ${ }^{100}$ This exception indicates a problem where there

\footnotetext{
94. RSA 1980, c. L-5.

95. Interpretation Bulletin IT-110R2, paragraph 11.

96. Id. paragraph 5.

97. Subsection 3501(1) Income Tax Regulations.

98. Paragraph 168(1)(d).

99. Clause 149.1(1)(e)(i)(A).

100. Clause 149.1(1)(e)(i)(B).
} 
is a condition that the property be held for 5 years. Even though such property could not be dealt with in years 1 through 4 , the disbursement requirement would still apply to such amounts in year 2 .

A donor's entitlement to a tax credit/deduction is independent of the effect of the gift on the donee's disbursement quota.

While the general rule is that consideration cannot be received by the donor without jeopardizing the tax benefit from the gift, there are circumstances in which the two elements can be combined. As an example, consider a parcel of real estate which an individual wishes to transfer to a charity, but in consideration for which the individual requires some return, the present value of which is less than the present value of the property. This could be structured in several ways:

(a) First, as a transfer of the property in consideration for an annuity from the charity. This is most appropriate if the property is itself income generating. The Department's administrative policy is that the annuity payments received by the transferor would be characterized as payments of principal only with no interest element. ${ }^{101}$ The result of the absence of an interest element is that the payments would be tax-free to the transferor. In addition, the transferor would be entitled to claim a deduction for the difference between the present value of the property and the aggregate (undiscounted) value of the annuity payments over the expected term of those payments. It is necessary in the context of an annuity to consider the Insurance Act ${ }^{102}$ which regulates such arrangements, if they are contingent upon life, as life insurance policies. The Department has confirmed to the author that a fixed term arrangement, which would not be covered by the Insurance Act, is nevertheless an annuity under the Income Tax Act and accordingly qualifies for this treatment. There are a number of valuation problems associated with less conventional types of annuities such as guaranteed term or joint term but in view of the provisions of the Insurance Act, most charities would not be able to issue those types.

(b) A second way of structuring the transaction would be for the transferor to sell the property to the charity in consideration for a promissory note and a series of instalment payments. Those instalment payments would likely be characterized as having an interest component. The transferor would then donate the promissory note back to the charity and claim a deduction for the amount of the promissory note. This would result in a larger donation for the transferor, but taxability on the interest portion of the instalments.

(c) A third possibility would be to give the property to the charity, reserving to the transferor a life interest in the property. The amount of the donation would be the value of the property, less the value of the life interest. The cost of the residual interest donated would be determined by pro-rating the cost of the property between the residual and life interests. ${ }^{103}$

101. Interpretation Bulletin IT-111R.

102. RSA 1980 c. I-5.

103. The Department's policy is discussed in Interpretation Bulletin IT-226. An arrangement which has certain similarities to a gift of a residual interest is a gift of an insurance policy. The Department's policy on such gifts is discussed in Interpretation Bulletin IT-244R2. 
It is important to realize that a disposition of property by way of gift is, generally speaking, treated as a disposition at fair market value. ${ }^{104}$ This means that, typically, the donor will have a capital gain (assuming that the donated property was capital property) and an offsetting charitable donation. Except to the extent that a capital gains exemption may be available, this often leaves a donor with a net tax liability because the donation is only recognized to the extent of $20 \%$ of income in each year. While this could be structured as a series of partial gifts, that would be the result under the Income Tax Act in any event as a result of the 5 year carryforward ${ }^{105}$ (unless that carryforward is not sufficient). In any event, a series of gifts would offer a much lower tax benefit to the donor on a discounted basis. There are several preferable ways of addressing this problem:

(a) One way around this problem is to structure the transaction as a donation to the Crown, because the $20 \%$ of income limitation does not apply in those circumstances. ${ }^{106} \mathrm{It}$ would be necessary to consider whether an agreement of the Crown to provide funds donated to it to a particular charity was consideration such that the donation would not be a gift.

(b) Another way around the problem is to characterize the property, if appropriate, as cultural property, which can eliminate the capital gain as well as eliminate the limitation on the donation. ${ }^{107}$ This is available only in very narrow circumstances.

(c) A third possibility which is available in many cases is an election ${ }^{108}$ which permits the donor to elect an amount, between the adjusted cost base (not undepreciated capital cost) and fair market value, that will be deemed to be the proceeds of the disposition in respect of the property and will also be deemed to be the amount of the donation for the purpose of determining the deduction/tax credit. Additional flexibility can be gained by combining this election with some of the possibilities mentioned above such as a donation in consideration for an annuity. The major problem with this election is that it is not possible to avoid a recapture of capital cost allowance.

The solicitation of donations is also regulated by the Public Contributions Act. ${ }^{109}$ Generally speaking, it requires municipal or provincial government approval of fund raising campaigns.

\section{Non-Profit Organizations}

Turning next to consider paragraph 149(1)(1), it exempts an organization from tax on its income if it was organized and operated exclusively for some purpose other than profit. It should be noted that this refers to the profit of the organization, not the profit of the members by way of dividend or other distribution. Accordingly,

104. Subparagraph 69(1)(b)(ii).

105. Paragraph 110.1(1)(a) and subsection 118.1(1) "total charitable gifts" and "total gifts".

106. Paragraph 110.1(1)(b) and the definition of "total gifts" in subsection $118.1(1)$. The limitation is instead income less the deduction in respect of charitable donations for corporations and total tax payable for individuals.

107. See the definition of "total cultural gifts" in subsection 118.1(1) and Interpretation Bulletin IT-407R2. See also the decision in Friedberg v. The Queen 89 DTC 5115 (FCTD).

108. Subsections $110.1(3)$ and $118.1(6)$.

109. R.S.A. 1980 c. P-26, as amended, and note that there are amendments enacted but unproclaimed. 
this provision is intended to exempt from tax an organization that is not operated for profit but which incidentally generates income.

There is no deduction or tax credit for donations to organizations exempt under this provision.

There have been a number of cases dealing with the interpretation of paragraph 149(1)(l):

1. Church of Christ Development Company Limited v. M.N.R. ${ }^{110}$ This case involved a non-profit company incorporated under the Companies Act. The Court commented that:

(a) The acceptance by an organization of donations, bequests, or funds for deposit and the investment of those funds for the purpose of earning investment income would not disqualify it from tax exempt status. An organization could be tax exempt yet still be active in its efforts to improve financial resources.

(b) The activity of the company in buying and selling stocks and bonds and in buying, subdividing, servicing and selling land was conducting a business in a way that could be distinguished from the simple investment of its funds.

One rather alarming comment made in the decision was that the payment of interest on an investment certificate issued to a member could itself place the non-taxable status of the organization in jeopardy. The same comment was made in respect of the prospect that, on winding up, the net assets would be payable to a related church which was also a member and in respect of the payment of a management salary to a member. The position is generally taken that the payment of a reasonable salary to an employee who is also a member of a registered charity is not a distribution of income to that member. The same position is taken with respect to distributions to other registered charities even if those registered charities are members. The constating documents of a registered charity may in fact expressly permit reasonable payments to any person for services actually rendered or for property actually transferred."'I

2. The Gull Bay Development Corporation v. The Queen ${ }^{112}$ - The organization had two basic activities - a logging business and social activities such as community clean-up, cutting wood for elderly residents, painting buildings, alcohol programs and similar programs. The court held that the corporation operated exclusively for non-profit purposes even though it raised funds for its social and welfare activities by a commercial lumbering enterprise.

3. Tourbec (1979) Inc. v. M.N.R. ${ }^{113}$ - This organization was established to provide subsidized travel and exchange opportunities for students. However, in order to subsidize students it required funds which it obtained by carrying on a travel agency business for profit at the same time. The Court held

110. 82 DTC 1461 (T.R.B.).

111. See paragraphs $6(1)(a), 6(2)(a)$, and $6(2)(b)$ of the Volunteer Incorporation Act for similar provisions.

112. 84 DTC 6040 (FCTD).

113. 88 DTC 1442 (TCC). 
that it was primarily operated for profit and accordingly was not exempt. The practical difficulty the organization apparently had was that it earned too much money from the for-profit portion of its business in the years for which it was audited and reassessed. It should have used its profit to provide the subsidized travel for students more quickly than it did.

\section{E. Implications of the General Anti-Avoidance Rule}

The much talked about general anti-avoidance rule ("GAAR") was enacted effective September 13, 1988. It is contained in Section 245 of the Income Tax Act. While there has been extensive comment on the provision, there is unlikely to be any judicial consideration of it for several years. Accordingly, definitive comment on the implications of this rule for charitable and non-profit organizations is not possible at this time. It is notable that the Department of National Revenue's Information Circular on $\mathrm{GAAR}^{114}$ does not contain any examples applicable to these types of organizations.

The following are some general comments on the potential applications of GAAR to charitable and non-profit organizations:

1. GAAR requires that there be a tax benefit which is defined as a tax reduction, avoidance, or deferral. ${ }^{115}$ It is not clear that a tax exempt status confers such a benefit. If it does not, GAAR could not apply to jeopardize that status.

2. Even if GAAR could apply, there would be a strong argument in the case of registered charities that the revocation of registration procedure is a more appropriate remedy if the status was being misused or abused. ${ }^{116}$

3. Gifts to registered charities which lead to deductions or credits clearly result in a tax benefit. However, the "detached and disinterested generosity" 117 of a gift should establish a primary bona fide purpose and exempt the benefit from GAAR. If the donation were for business promotional purposes, there again should be a primary bona fide purpose. For there to be a gift where the primary purpose was to obtain the credit or deduction, it would likely be necessary that the gift be structured using one of the methods described above. A case that would clearly raise a GAAR issue is Friedberg v. The Queen. ${ }^{118}$ It involved a gift of Canadian cultural property immediately following its acquisition where the unimpeached appraisals were for a far higher amount than the acquisition price. As a result of the rules governing cultural gifts, the taxpayer obtained tax savings far in excess of his outlay. The difficulty in applying GAAR is that the rules governing gifts of cultural property were intended to offer a tax incentive to such donations so there may be no abuse or misuse. However, it may be argued that the rules were to remove disincentives from making such donations rather than to create incentives to acquire property to donate. ${ }^{119}$

114. Information Circular IC 88-2.

115. Subsection 245(1).

116. Section 168.

117. Tite, supra n.92 at 1791.

118. Supra n.107.

119. For an analysis of the potential application of CAAR to this fact situation, see McDonnell, "Current Cases" (1989) 37:2 C.T.J. 408. 


\section{CONCLUSION}

Notwithstanding the large number of charitable and non-profit organizations, the large number of Albertans involved in these organizations, and the magnitude of the assets of many such organizations, insufficient attention has been paid to the legal framework within which these organizations operate. It is hoped that the prospects for reform in corporate law and the recent flurry of tax cases will encourage further consideration of these issues. 